Kudak K. M., PhD, Research Fellow Mashiko K. S., PhD, Deputy Director for Research Zakarpattya Regional Center for Socio-Economic and Humanitarian Research of the National Academy of Sciences of Ukraine Uzhhorod, Carpathian region, Ukraine

DOI: https://doi.org/10.30525/978-9934-26-064-3-32

\title{
INCOME INEQUALITIES AMOG ETHNIC MINORITIES IN A POLYETHNIC REGION
}

One of the characteristic features of any socio-economic system is income inequality that consequently leads to significant differences in the quality of life, and thus, it affects the human capital. The study of income inequality requires special attention in polyethnic regions such 
as Transcarpathia. As part of the study held by Zakarpattya regional center for socio-economic and humanitarian research of the National Academy of Sciences of Ukraine, a sociological survey was conducted. It involved representatives of the following ethnic groups of the Transcarpathian region: Ukrainians (252 people), Hungarians (70 people), Roma (30 people), Romanians (25 people), Slovaks (15 people), Russians (16), other ethnic groups such as Poles, Jews, Georgians, Rusyns (Ruthenians), Czechs (10 people). The study identified interethnic differentiations within the current quality of life and defined most typical income-related problems as well as stated the high level of deprivation of certain ethnic groups in the region.

The analysis of the structure of incomes and expenditures of the ethnic minorities in the Transcarpathian region showed that the highest share of the population with total income below the relative poverty level is observed among the Roma population (86.67\%), whereas the lowest one is among Slovaks and Romanians - 13.33\% and $13.63 \%$ respectively.

In the overall structure of ethnic households' income, the highest share is taken by salary - 66.94\% (especially Slovaks - 83\% and Hungarians $-72.95 \%$ ), then entrepreneurial profit $-8.69 \%$ (Russians $16.7 \%$ and Ukrainians - 10.76\%), pension - 8.51\% (Russians $18.33 \%$, Slovaks - 15.31\%, Roma - 13.3\%), and labour migration incomes $-7.65 \%$ (Romanians $-15 \%$, Ukrainians $-10.5 \%$, Slovaks $6.66 \%)$.

It is stated that in the overall structure of household expenditures, the share of consumer expenditures is the highest, as indicated by $54.55 \%$ of respondents (including Slovaks - 100\%, Ukrainians $54.37 \%$ Roma $-53.33 \%$, Hungarians $-52.8 \%$ ). A significant part of expenditures goes on construction and repair of housing $-37.32 \%$ of respondents (including Slovaks - 100\%, Roma - 46.67\%, Romanians $41.43 \%$ ) and children's education $-33.97 \%$ of respondents (including Slovaks $-100 \%$, Romanians $-44.29 \%$, others $-50 \%$ ). Objectively, the share of expenditures on saving is very low, as indicated by $23.92 \%$ of respondents (Roma - 0\%, Romanians - 4\%, Slovaks $13.33 \%$ ), as well as the development of own business $-13.88 \%$ 
(Romanians $-48 \%$, Hungarians $-17.14 \%$, Ukrainians $-13.10 \%$ ). The analysis of households' consumer expenditures showed that they mainly take $75-100 \%$ of income (Roma $-63.33 \%$, Russians $61.54 \%$, Hungarians $-53.85 \%$ ). In whole, such results reflect the low level of investment potential of the population under analysis.

The study paid special attention to the analysis of subjective assessment of households' satisfaction with their financial condition, which indicated a rather low level of satisfaction among the respondents. In particular, $44.37 \%$ of respondents rated their income level as very low (1-2 points). In particular, $92.59 \%$ of Roma scored these points. While $38.73 \%$ of the population gave an average score (3-5 points) $-66.67 \%$ Romanians, $50 \%$ of Ukrainians, $45.83 \%$ of Hungarians, and only $4.23 \%$ of respondents rated their satisfaction with their incomes as high (9-10 points) $-16.67 \%$ of Romanians, $6.25 \%$ of Ukrainians and $4.17 \%$ of Hungarians. In general, the study showed that $17.22 \%$ of respondents consider themselves as poor (including $80 \%$ of Roma, $56.25 \%$ of Russians, $50 \%$ - others).

\section{References:}

1. The quality of life of the region's population in the ethno-demographic dimensions. REPORT ON RESEARCH WORK. № 0119U102879. ZRC SEGD NAS of Ukraine. Uzhhorod, 2019. 186 p. 